Мирко Обрадовић

Универзитет у Београду

Филозофски факултет

Одељење за историју

mdobrado@f.bg.ac.rs
Оригиналан научни рад

примљено: 1. јул 2012

прихваћено: 1. октобар 2012

\title{
ХЕРОЈСКО ИМЕ АНТИЛОХ КАО ЛИЧНО ИМЕ КОД ХЕЛЕНА
}

Сажетак: У раду се истражује херојско грчко име Антилох и његова дистрибуција као личног имена у хеленском свету. На богатом антропонимијском материјалу из различитих делова грчког света анализирају се могући разлози за давање овог херојског имена смртним људима. Бројни примери који су наведени у истраживању извесно показују да је лично име Антилох давано у историјским епохама потомству са јасном свешћу да је херојско и нелеидско. Аутор идентификује три основна разлога који су допринели популарности овог имена као личног имена у старој Грчкој уопште, а нарочито у појединим областима хеленског света, као што су Атика, Јонија, Тесалија, острво Родос: 1) пошто је реч о хероју истакнутом у традицији о Тројанском рату, име Антилох је могло бити прихватљиво свим Грцима и могло би се зато најпре посматрати као панхеленско и од значаја за све Хелене; 2) име Антилох је, с друге стране, као нелеидско име било прихватљиво нарочито Јоњанима, одакле се може тумачити и његова популарност у Атици, али и у другим јонским крајевима, наиме на острвима у Егејском мору, као и у малоазијској Јонији; 3) име Антилох је, осим тога, као лично име присутно и у Тесалији где је према истој нелеидској генеалогији херој Антилох могао бити подједнако сматран и локалним тесалским херојем; уједно као пријатељ Ахилеја, највећег ахајског јунака под Тројом, али и националног хероја Тесалаца, херој Антилох је био необично цењен код Тесалаца, па је и његово име могло у традицији добити посебну „тесалску“ боју. Овим разлозима би се најпре могле објаснити потврде овог имена као личног имена у градовима Тесалије, посебно у класичном и хеленистичком периоду.

Кључне речи: Антилох, грчка антропонимија, Нелеиди, етимологија, грчка епика, мит, историја, политика, културне вредности.

Имена преузета из херојског репертоара грчких имена јављају се као антропоними у готово свим периодима хеленске историје. Иако чине само један, по свом обиму мањи сегмент старе грчке антропонимије, херојска имена и имена изведена од имена хероја представљају важан изворни материјал за историчаре јер омогућују боље разумевање старе хеленске историје и помажу стварању јасније слике о одређеним историјским догађајима и процесима. Како је поглед на свет 
хероја нешто што је јединствено свим Хеленима, а не може се наћи код других народа, тако су и херојска имена стари Грци давали својој деци намерно и са погледом на хероје који су носили ова имена. Не само да су сматрали да су херојски поступци идеал и образац понашања коме смртни људи треба да теже, већ су и преко личних имена настојали да се што ближе повежу са херојима, а преко њих и са бесмртним боговима.

Међу херојским именима која су извршила снажан утицај на хеленску антропонимију историјских епоха значајно место припада такозваним нелеидским именима, односно именима која су у грчком миту и традицији носили велики херој

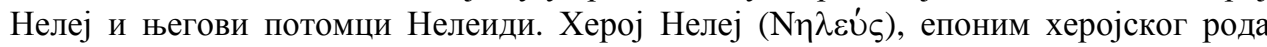
Нелеида, био је према грчком миту син бога Посејдона и Тире, а брат близанац Пелије, потоњег грамзивог владара Јолка у Тесалији. Иако родом Тесалац, Нелеј је срећу потражио на Пелопонезу где је основао град Пил и постао родоначелником славне владарске породице. ${ }^{1}$ Овога Нелеја треба разликовати од његовог истоименог потомка Нелеја, кога је традиција, првенствено атинска, учинила сином последњег атинског краља Кодра, и за кога се везује предводништво у тзв. Јонској колонизацији, односно насељавању Грка у делу малоазијског приморја које ће временом почети да се назива Јонијом. ${ }^{2}$ Од непосредних Нелејевих потомака највећу славу досегао је, међутим, његов син Нестор (N乏́ $\sigma \tau \omega \rho)$. Као краљ Пила и један од великих хероја грчке епике (са важном улогом у оба хомерска епа), Нестор симболизује мудрост, искуство, срећну и крепку старост. Он је уједно и учесник готово свих у хеленској традицији слављених јуначких подухвата и сага: Тројанског рата, борбе Лапита и Кентаура, лова на Калидонског вепра, чак и похода Аргонаута. $^{3}$ Због тога се и Несторово име могло учинити привлачним и пожељним за давање деци са нарочитим погледом на Несторово јуначко потомство са којим су настојале да се идентификују поједине аристократске породице из различитих делова грчког света. На тај начин се и име Нестора, као и имена његових синова

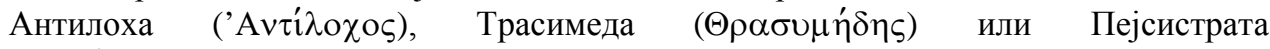

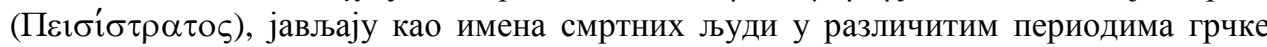
историје. Због свог значаја сва ова херојска имена добила су временом панхеленски карактер, односно постала су, као и сами хероји, прихватљива свим Грцима и могла су бити давана потомству са свешћу и жељама да у животу поступају попут наведених хероја. Осим поменутих, било је, без сумње, и других херојских имена

\footnotetext{
1 За богату традицију о Нелеју, његовом пореклу и рођацима, херојским подвизима и судбини његових непосредних потомака, упор. Weizsäcker, Roscher III 1, 1897-1902, 104-111, s.v. Neleus (1); van der Kolf, RE 16, 1935, 2269-2280, s.v. Neleus (1); T. Gantz, Early Greek Myth. A Guide to Literary and Artistic Sources, Baltimore 1993, 184-189.

${ }^{2}$ О Нелеју, Кодровом сину, упор. Weizsäcker, Roscher III 1, 1897-1902, 111-113, s.v. Neleus (2); F. Prinz, Gründungsmythen und Sagenchronologie (Zetemata 72), München 1979, 325-340; A. Herda, Der Kult des Gründerheroen Neileos und die Artemis Kithone in Milet, Jahreshefte des Österreichischen Archäologischen

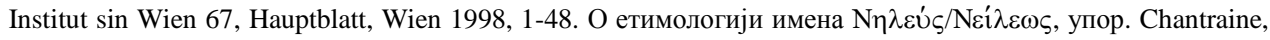
DELG, 745, 750-51.

${ }^{3}$ Упор. J. Schmidt, RE 17, 1936, 108-123, s.v. Nestor (1); H. Erbse, Nestor und Antilochos bei Homer und Arktinos, Hermes 121, Stuttgart 1993, 385-403; E. Visser, Homers Katalog der Schiffe, Stuttgart und Leipzig 1997, 508-531; E. Visser, DNP 8, 2000, 861-863, s.v. Nestor (1).
} 
која се на посредан или непосредан начин могу довести у везу са Нелеидима, а која су опет потврђена као имена смртних људи. У претходном броју овог истог

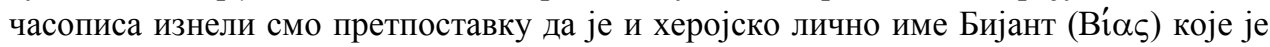
носио Бијант из Пријене, један од седморице мудраца архајске епохе, могло настати као резултат стварних или измишљених веза истакнуте јонске племићке породице из малоазијске Пријене са херојским Нелеидима и Пилом у Месенији. ${ }^{4}$

Када се говори о именима непосредних Несторових потомака, име

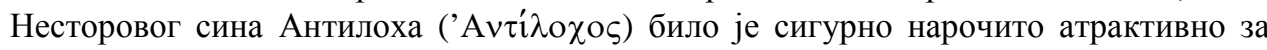
давање деци. Разлоге за то треба тражити у чињеници да Антилох као херој носи многе особине које су у сваком друштву, а код Хелена нарочито, морале бити посебно на цени. Пошто је мудри Нестор у време Тројанског рата већ био прилично стар, Антилох је у походу на Троју био један од стварних ратних вођа, бар када је реч о контигенту пристиглом из Пила (другом по величини са 90 ратних лађа међу ахајским контигентима у хомерском Каталогу бродова из другог певања Илијаде). Иако по годинама један од најмлађих, Антилох је исто тако већ код Хомера и један од најхрабријих и појавом најпривлачнијих ахајских ратника под Тројом. ${ }^{5}$ Он је управо и први од Ахајаца који у борби убија противника, Тројанца Ехепола, у старијем од хомерских епова. ${ }^{6}$ У надметањима које је Ахилеј приредио у част палог Патрокла, Антилох се нарочито истакао у трци коњских двоколица. Наиме, Антилох је у трци имао озбиљне противнике у великим херојима Диомеду, Еумелу, Менелају и Мериону, па иако је од свих такмичара имао најспорије коње, добио је савет од оца Нестора како да тај свој хендикеп надомести памећу и лукавством (mêtis). ${ }^{7}$ Победу је уз помоћ богиње Атене однео Диомед, а Антилох је успео мудром вожњом да својим колима престигне Менелаја и освоји другу награду. Међутим, по завршетку такмичења, незадовољни и љути Менелај је позвао Антилоха да се закуне да овај није варао у трци, а Антилох је смирено, као прави син мудрог Нестора, избегао даљу конфронтацију, упутио извињење Менелају и предао му кобилу која је била намењена као награда другопласираном у трци. Менелај је на тај „часни“ поступак Антилоха одговорио тако што му је вратио награду и хероји су се свечано измирили. ${ }^{8}$ С друге стране, брзоноги Антилох је узео учешћа и у трчању, али је у тој дисциплини завршио као трећи иза Одисеја и малог

\footnotetext{
${ }^{4}$ М. Обрадовић, Мудраи Бијант из Пријене: традииија о времену у којем је живео, његовом пореклу и значењу његовог имена, Истраживања 22, Нови Сад 2011, 65-74.

${ }^{5}$ Il. XIII 394-401; XV 568-571. Упор. R. Janko, The Iliad. A Commentary, Vol. IV, Books 13-16, Cambridge 1994, 97-8, 290.Упор. такође Od. III 11-12, где управо Нестор за свог сина Антилоха каже да је по свему био беспрекоран и „одличан тркач и борац“, као и Od. IV 199-202, речи Антилоховог брата Пејсистрата у Спарти пред Менелајем.

${ }^{6}$ Il. IV 457-462. Упор. G. S. Kirk, The Iliad. A Commentary, Vol. I, Books 1-4, Cambridge 1985, 385-86.

${ }^{7}$ Il. XXIII 301-350. Упор. M. Gagarin, Antilochus' Strategy: The Chariot Race in Iliad 23, Classical Philology 78, Chicago 1983, 35-39; H. Roisman, Nestor's Advice and Antilochus' Tactics, Phoenix 42, Toronto 1988, 114 120; N. Richardson, The Iliad. A Commentary, Vol. VI, Books 21-24, Cambridge 1993, 208-213.

${ }^{8}$ Il. XXIII 402-447; 566-614. Упор. N. Richardson, The Iliad. A Commentary, Vol. VI, Books 21-24, Cambridge 1993, 214-219, 224-236.
} 
Ајанта. Због свог понашања добио је, међутим, од Ахилеја похвалу и додатну награду. ${ }^{9}$

У вези са такмичењем које је приредио Ахилеј важно је нагласити да је у миту о Антилоху посебно наглашена чињеница да је он миљеник Ахилеја, највећег ахајског хероја под Тројом. Антилох се заправо већ код Хомера, али и у каснијој традицији, јавља као нека врста другог Патрокла и замене за Патрокла. Није случајно да је баш он у Илијади тај херој који Ахилеју доноси тужну вест о Патрокловој погибији. ${ }^{10}$ И након смрти се Антилох доводи непосредно у везу са Ахилејем, а песник Одисеје наводи да у Хаду заједно бораве душе Ахилеја, Патрокла, Антилоха и Ајанта. ${ }^{11}$ Познија традиција зна и да Антилох, заједно са Патроклом и Хеленом, сада као Ахилејевом женом, прави друштво бесмртном Ахилеју на острву Леуки у Црном мору. ${ }^{12}$ Тако се у миту о Антилоху заправо издвајају два подједнако важна момента: однос према оцу Нестору и однос са Ахилејем. Оба су од суштинског значаја за његов статус као хероја. То се да најбоље видети на основу приказа даљих догађаја под Тројом о којима се не пева у Илијади, али који су били детаљно описани у несачуваном епу Етиопиди: тројански савезник Мемнон, краљ Етиопљана, убио је Антилоха, када је овај практично себе жртвовао у борби да би спасао свог старог оца Нестора, а Ахилеј је, с друге стране, убио Мемнона, и на тај начин „осветио“ свог миљеника Антилоха. ${ }^{13}$ Ако за тренутак и занемаримо ову везу Ахилеја са Антилохом, толико је сам поступак Антилоха, који је чак жртвовао свој живот да спасе очев, био цењен код Хелена, да

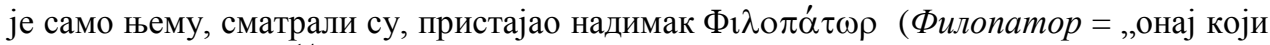
воли свога оца“). ${ }^{14}$ Такви поступци су Антилоху обезбедили вечну славу у

\footnotetext{
${ }^{9}$ Il. XXIII 740-797.

${ }^{10}$ Il. XVIII 1-34. Упор. M. W. Edwards, The Iliad. A Commentary, Vol. V, Books 17-20, Cambridge 1991, 141147.

${ }^{11}$ Od. XI 467-470. Упор. такође Od. XXIV 71-84, за заједничку хумку крај Хелеспонта где су положени остаци костију хероја Ахилеја, Патрокла и Антилоха. И Антилоху су на том месту (код Сигеја) становници каснијег Илиона указивали херојске почасти напоредо са највећим ахајским херојима палим под Тројом - Ахилејем, Патроклом и Ајантом. Упор. Strab. XIII 1, 32, где се такође наводи да су се код Сигеја, поред Ахилејевих, налазила и обележја (тпетаta) Патрокла и Антилоха.

${ }^{12}$ Paus. III 19, 11.

${ }^{13}$ Од сачуваних античких извора о овом значајном догађају под Тројом први пева Пиндар, Pyth. 6, 28ff., мада је прича о Антилоховој жртви морала бити већ добро позната у архајској епоси, када је о њој певао песник Етиопиде. Да је тројански савезник Мемнон убио Антилоха, зна извесно већ и песник Одисеје, IV 186-188. Управо епизода са Мемноном, Антилохом и Ахилејем, која у многим важним детаљима подсећа на судбину Патрокла и Ахилејеву освету описану у Илијади, представља једно од најјачих упоришта тзв. неоаналиста; они држе да Етиопида, а можда и неке друге песме тројанског кикла (попут Киприје) по времену настанка претходе Илијади и да су могле послужити песнику Илијаде као директна инспирација. О овом проблему постоји велика и разноврсна литература: упор. нпр. H. Erbse, Nestor und Antilochos bei Homer und Arktinos, Hermes 121, Stuttgart 1993, 385-403; K. Dowden, Homer's Sense of Text, Journal of Hellenic Studies 116, London 1996, 47-61; J. S. Burgess, Beyond Neo-Analysis: Problems with the Vengeance Theory, American Journal of Philology 118, Baltimore 1997, 1-19; J. S. Burgess, The Tradition of Trojan War in Homer and the Epic Cycle, Baltimore 2001; M. L. West, Iliad and Aethiopis, Classical Quarterly 53, Oxford 2003, 1-14

${ }^{14}$ Како то већ јасно дефинише, на пример, велики грчки писац и историчар Ксенофонт у IV веку пре н.е. Упор. Xen. Cyn. I 14.
} 
хеленској традицији, па је сходно томе и његово име постало пожељно у избору имена која су давана мушкој деци.

Остављајући по страни мит, лично име Антилох по свом образовању није ни необично, нити у нечему нарочито посебно. Једно је од честих грчких образовања са предлогом 'Av $\tau-,{ }^{15}$ и готово не мање забележених завршетака личних имена на $-\lambda о \chi о \varsigma$ (именица $\lambda o ́ \chi 0 \varsigma$ у основном значењу „чета, војна дружина“, али такође и „заседа“), који су изведени од глагола $\lambda \dot{\varepsilon} \chi о \mu \alpha$, или, што је

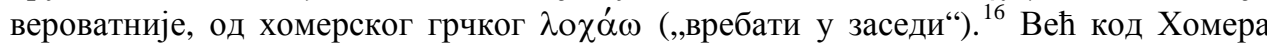
имена која се завршавају на $-\lambda \circ \chi \circ \varsigma$ су честа (нпр. 'А

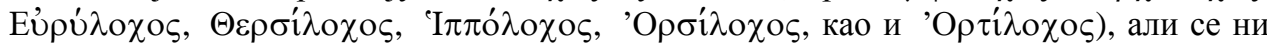

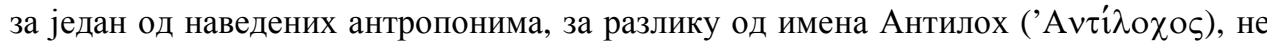
може рећи да је баш уобичајен као лично име смртних људи у различитим епохама старе хеленске историје. Име Антилох, с друге стране, срећемо као лично име у свим епохама и у готово свим крајевима хеленског света. Тако није необично што се име Антилох као лично име среће и у Риму у периоду Царства. ${ }^{17}$ Дистрибуција овог антропонима, није, међутим, ни приближно подједнака у свим грчким земљама. Највише историјских Антилоха је потврђено у Атици у различитим епохама старе грчке историје, од архајске епохе па све до периода Римског царства. С друге стране, име Антилох је као лично име доста ретко потврђено на Пелопонезу и на Западу уопште (оксфордски Лексикон грчких личних имена, LGPN III A, који обухвата Пелопонез, северозапад Грчке и све хеленске насеобине на западу бележи само 5 потврда овог имена), ${ }^{18}$ и како изгледа, није толико карактеристично за Дорце. ${ }^{19}$ Треба, истине ради, нагласити да, остављајући Атику по страни, далеко

\footnotetext{
${ }^{15}$ Упор. већ F. Bechtel, Die historischen Personennamen des Griechischen bis zur Keiserzeit, Halle 1917, 5860, за десетине примера оваквих имена. Упор. такође Н. von Kamptz, Homerische Personennamen: sprachwissenschaftliche und historische Klassifikation, Göttingen 1982, 183, где су побројана и анализирана

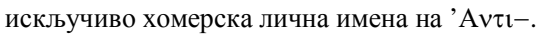

${ }^{16} \mathrm{H}$. von Kamptz, Homerische Personennamen: sprachwissenschaftliche und historische Klassifikation,

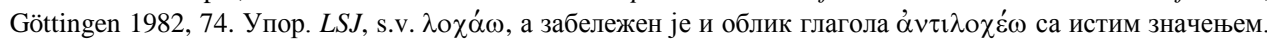
Упор. такође Chantraine, DELG, 634-35, s.v. $\lambda \dot{\varepsilon} \chi \varepsilon \tau \alpha 1$.

${ }^{17}$ Упор. H. Solin, Die griechischen Personennamen in Rom. Ein Namenbuch, I, Berlin, New York 1982, 21.

18 Једине сигурне потврде долазе из грчких колонија на илирској обали: у Епидамну (Дирахију) у хеленистичком периоду као име епонимног магистрата притана (prytanis) на новцу и цреповима, LGPN IIIA, s.v. Antilochos (3) - (4). Упор. R. Münsterberg, Die Beamtennamen auf den griechischen Münzen, repr. Hildesheim, Zürich - New York 1985, 38; I. Epidamnos 531. Антилох се звао и отац извесног Филипа чији је надгробни споменик из познохеленистичког периода пронађен на територији грчког града Аполоније у Илирији (I. Apollonia 162). Упор. LGPN IIIA, s.v. Antilochos (2).

${ }^{19}$ Антилох потврђен у дорском Епидауру на Пелопонезу око 370 . године пре н.е. (IG IV 1 1, 102, 270), не мора нужно бити грађанин Епидаура, већ је, можда, пре реч о странцу. Упор. LGPN IIIA, s.v. Antilochos (1). С друге стране, од дорских градова и насеобина на Понту (Црном мору), име Антилох је као лично име најбоље потврђено у граду Херсонесу на полуострву Криму: најстарија од тих потврда урезана на једном остракону извесно потиче већ из друге половине V века пре н.е. (SEG 40, 612. 16). Упор. LGPN IV, s.v. Antilochos (2). Остале потврде су знатно позније и ниједна није пре периода Римског царства (II века н.е.). Упор. LGPN IV, s.v. Antilochos (3)-(8). Из дорског Калхедона/Халкедона код Босфора сигурно

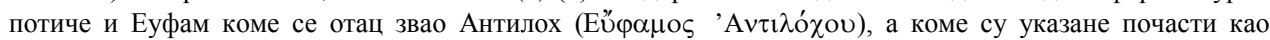
војном заповеднику у хеленистичком периоду. Упор. I. Kalchedon 6; LGPN VA, s.v. Antilochos (1).
} 
највише потврда имена Антилох као личног имена долази са доминантно дорског острва Родоса (види ниже).

Не може се, међутим, рећи да је име Антилох као лично име, на основу тога што је рано потврђено у Атини, али и у другим јонским областима, од почетка имало посебну „јонску“ боју. Пре би се дало закључити да је оно, због свих наведених добрих особина и универзалних вредности које се везују за хероја Антилоха, носило панхеленски карактер. Ипак, не чуди што је име Антилох као антропоним у Атини забележено доста рано, а временски најранија потврда сигурно потиче из архајског периода. Можда се тако звао већ један Атињанин који је могао бити рођен негде у првој половини VII века пре н.е, а чије је име забележено на једном суду из, отприлике, средине VII века (уколико у наведеном случају није управо реч о самом хероју Антилоху). ${ }^{20}$ Извесно је, међутим, да се Антилох звао Атињанин, чији нам је надгробни споменик из средине VI века сачувао фрагменте лепог, стихованог натписа. ${ }^{21} \mathrm{C}$ друге стране, у класичном и хеленистичком периоду, име Антилох као лично име добро је потврђено у неколико атичких дема. Од укупно 17 атинских Антилоха (забележених у оксфордском Лексикону грчких личних имена, $L G P N$ II), у деми Скамбониди је у IV веку пре н.е. име Антилох као антропоним забележено у чак три случаја. ${ }^{22}$ Исто лично име такође срећемо у наведеном периоду и у деми Флији, где се готово извесно Антилох звао отац једног Антемиона, као и у деми Атмонону, где је исто име носио отац неког Филокла. ${ }^{23}$ Из IV века пре н.е. је и Антилох, отац Питокла, из деме Еупириде, а у ранохеленистичком периоду Антилох се звао и отац извесног Диона из деме Ламптре. ${ }^{24}$ Име Антилох се готово сигурно да допунити и на натпису који бележи чланове једне атинске симорије из средине IV века. ${ }^{25}$

Још неколико највероватније атинских потврда имена Антилох из класичног периода заслужују посебну пажњу. На острву Лемносу, где је у класичном периоду постојала атинска клерухија (насеобина атинских грађана), Антилох се већ звао и један филозоф, који се у традицији наводи као противник и критичар Сократа. ${ }^{26}$ Иако Диоген Лаертије, писац биографија грчких филозофа,

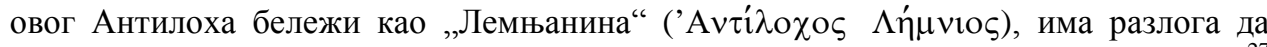
верујемо да је заправо реч о атинском грађанину, атинском клеруху на острву, ${ }^{27}$

\footnotetext{
${ }^{20}$ SEG 34, 49. Упор. LGPN II, s.v. Antilochos (17).

${ }^{21} I G \mathrm{I}^{3} 1208$ (датовање око 530. године пре н.е.). Упор. LGPN II, s.v. Antilochos (1).

${ }^{22}$ LGPN II, s.v. Antilochos (13) - (15).

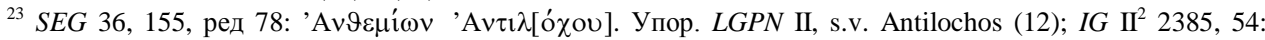
$\Phi \imath \lambda \circ \kappa \lambda \tilde{\eta} \varsigma^{\prime} A v \tau \imath \lambda o ́[\chi 00]$. Up. LGPN II, s.v. Antilochos (6).

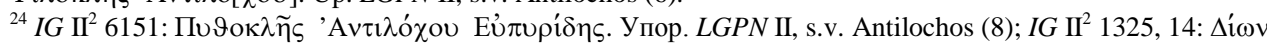

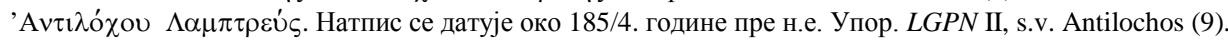

${ }^{25}$ IG II ${ }^{2}$ 1616, 96. Упор. LGPN II, s.v. Antilochos (2); J. K. Davies, Athenian Propertied Families 600-300 B.C., Oxford 1971, 37, датује документ између 356. и 340. године пре н.е.

${ }^{26}$ Diog. Laert II 46, 7, цитирајући Аристотелов спис O песништву. Упор. RE s.v. Antilochos (6).

${ }^{27}$ О атинској клерухији на острву Лемну из средине V века пре н.е, упор. R. Meiggs, Athenian Empire, Oxford 1972, 424-425.
} 
кога је зато најприродније придодати списку „атинских Антилоха“ у LGPN II. ${ }^{28}$ Није довољно јасно порекло још једног Антилоха, који је отприлике у истом периоду (крај V века пре н.е.), забележен као песник похвалних и удворичких стихова у част Лисандра, славног спартанског науарха и победника над Атињанима у Пелопонеском рату. ${ }^{29}$ Веома мало знамо и о извесном историчару Антилоху, као и о нешто млађем (хеленистички период) Антилоху, који се спомиње као писац историје филозофа од Питагоре до Епикура. ${ }^{30}$ Вероватно је неко од наведених писаца, ако већ нису сви, био родом Атињанин и атински грађанин. С друге стране, у хеленистичком периоду (крај II века пре н.е.) у Делфима је на листи ефеба

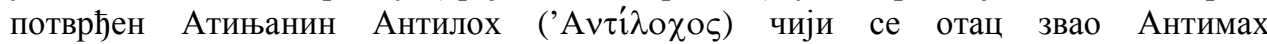

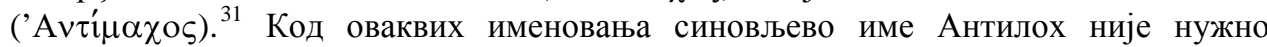
морало бити дато са погледом на хероја Антилоха, већ би такође могло да се ради о добро познатој пракси код Хелена да се мушком детету не даје дословно очево име,

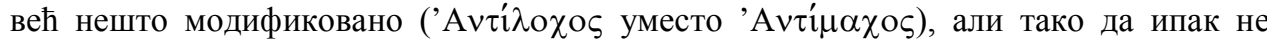
оставља места сумњи одакле је изведено. То се у пракси најчешће постизало задржавањем и истицањем карактеристичних делова имена. Наравно, син је могао носити и дословно очево име, како то управо добро показује пример Антилоха, сина Антилоховог, из деме Пајаније на листи атинских већника из периода Царства (16970. год. н.е.). ${ }^{32}$ У вези с тим, треба нагласити да је име Антилох је у Атини остало популарно и у периоду Римског царства, јер је потврђено још неколико пута у току II и III века н.е. ${ }^{33}$ Хронолошки последњи потврђени атински Антилох из средине III

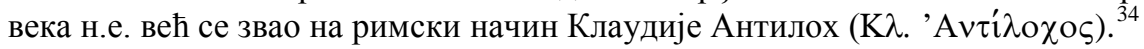

Од осталих области и градова јонског света, нарочито су занимљиве ране потврде херојског имена Антилох као личног имена на натписима са острва Тасоса и то у угледним породицама из којих су бирани највиши магистрати. Најстарији сачувани пример потиче још из архајског периода када је на једној листи теора

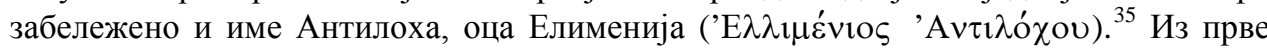

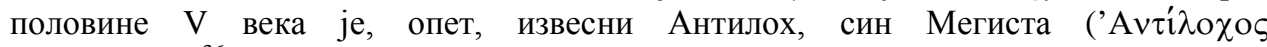
$\mathrm{M \varepsilon}[\gamma] i \tau \tau \varepsilon \omega){ }^{36}$ Сасвим је могуће да је код ових именовања важну улогу имала чињеница да је реч о нелеидском имену и да је била присутна тежња да се направи

\footnotetext{
${ }^{28}$ Исти Антилох „филозоф“ уврштен је као Лемњанин у први том оксфордског Лексикона који обухвата грчка острва у Егејском мору. Упор. LGPN I, s.v. Antilochos (3).

${ }^{29}$ Plut. Lys. 18, 4. Плутарх овде вероватно следи историчара Дурида са Сама, наводећи да је Лисандар толико био задовољан Антилоховим песничким умећем да му је поклонио пехар пун сребра. Упор. $R E$ s.v. Antilochos (3).

${ }^{30}$ Податке о њима оставио је велики хришћански писац и учитељ Климент Александријски (Strom.I 80; I 309 В). Можда истог Антилоха, писца историје грчких филозофа, спомиње и Дионисије из Халикарнаса (De compos. verb. 4). Упор. RE s.v. Antilochos (4)-(5).

${ }^{31}$ FD III 2, 25 III, 26. Упор. LGPN II, s.v. Antilochos (4).

${ }^{32}$ Упор. Ag. XV 378, 17; LGPN II, s.v. Antilochos (10) - (11).

${ }^{33}$ SEG 29, 152 I, 35. Упор. LGPN II, s.v. Antilochos (7); IG II 2211/12, 70. Упор. LGPN II, s.v. Antilochos (16).

${ }^{34} I G \mathrm{II}^{2} 2245,31$. Упор. LGPN II, s.v. Antilochos (5).

${ }^{35}$ IG XII 8, 275, 8 (датовање извесно пре 510. године пре н..е.). Упор. LGPN I, s.v. Antilochos (21).

${ }^{36}$ Ét. Thas. III, pp. 262 ff. Cat. I, III, 18. Упор. LGPN I, s.v. Antilochos (22).
} 
јасна генеалошка веза са светом хероја, па је стога и име Антилох било нарочито атрактивно за давање деци у оквиру аристократских породица на острву. Подсећање на херојско порекло, макар и у форми давања херојског имена потомству, карактеристично је за племићке породице у грчким градовима архајске и класичне епохе. С друге стране, име се Антилох као лично име није морало увек и нужно јавити у свом пуном облику, већ је, исто тако, могло бити забележено и у скраћеном облику, као хипокористик. Такав би случај најпре могао бити са извесним Антилом

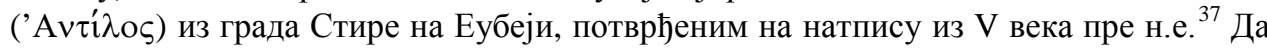
је херојско име Антилох као лично име било присутно на јонској Еубеји, потврђује опет документ из, највероватније, III века пре н.е. из града Кариста. ${ }^{38}$ Са острва Еубеје долази још једна занимљива потврда херојског имена Антилох у патронимичком облику. У граду Еретрији на Еубеји међу бројним епитафима из IV и III века пре н.е. пронађен је и надгробни споменик за грађанина јонског града Кизика у Малој Азији Филарха чији се отац највероватније звао Антилохид

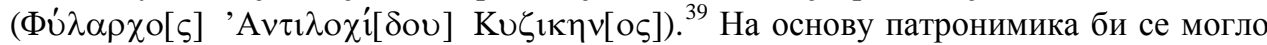
претпоставити да се још деда или прадеда овог грађанина Кизика (колонија јонског града Милета на Пропонтиди) звао Антилох, па се због тога у породици име јавља у

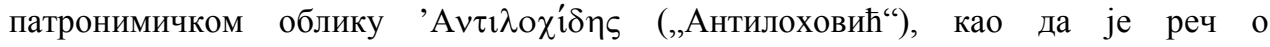
Антилоховом потомку.

Херојско име Антилох је, нема сумње, доживљавано као панхеленско, али с обзиром да је нелеидско, могло је бити сматрано и за „ексклузивно“ јонско, што донекле показују и потврде овог антропонима у градовима малоазијске Јоније. Истина, хронолошки најраније потврде имена Антилох као личног имена у Јонији потичу из ранохеленистичке епохе. Тако се име Антилох као лично име јавља у Смирни у једној дугој листи даваоца прилога на натпису из III века пре н.е. ${ }^{40}$ У Колофону је опет ово име већ крајем IV века сигурно потврђено као име монетарног магистрата. ${ }^{41} \mathrm{C}$ друге стране, на графитима из Милета, који нису једноставни за датовање, између осталих имена, забележено је извесно и име Антилох

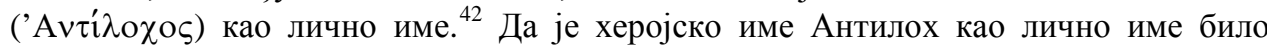
добро заступљено у градовима малоазијске Јоније, показују такође и потврде из познохеленистичке Пријене. ${ }^{43}$ Посебно је, међутим, занимљив стиховани натпис на једној посвети Хермесу у граду Магнесији на Меандру у III веку пре н.е, где се као потписани уметник представио извесни Антилох. ${ }^{44}$ Из Халикарнаса, који је још у

\footnotetext{
${ }^{37}$ IG XII 9, 56, 21. Упор. $L G P N$ I, s.v. Antilos. Истине ради, у овом случају не мора нужно бити реч о

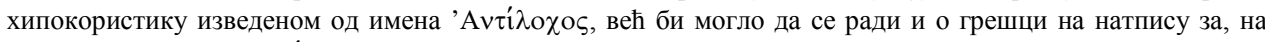
пример, лично име 'Avті́ $\lambda \alpha о \varsigma$.

${ }^{38}$ Почасни декрет града за грађанина Кариста који се звао Антилох, публикован са коментаром у D. Knoepfler, Carystos et les Artémisia d'Amarynthos, Bulletin de Correspondance Hellénique 96, Athènes 1972, 283-88. Упор. LGPN I, s.v. Antilochos (1).

${ }^{39}$ SEG 28, 725, С 176. Упор. LGPN VA, s.v. Antilochides.

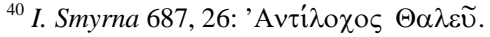

${ }^{41}$ Између, отприлике, 320. и 310. године пре н.е. Упор. LGPN VA, s.v. Antilochos (6).

${ }^{42}$ Milet I 9, 325 (SEG 4, 425).

${ }^{43}$ I. Priene 313, 73; 313, 148 (І век пре н.е. или I век н.е.). Упор. LGPN VA, s.v. Antilochos (8)-(9).

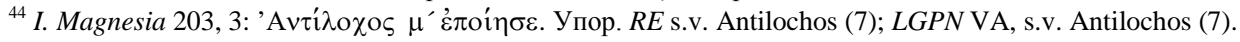


класично доба постао доминантно јонски град, такође је занимљива посвета Хераклу и Хермесу коју је начинио Меланта, Антилохов син, надзорник дечака у

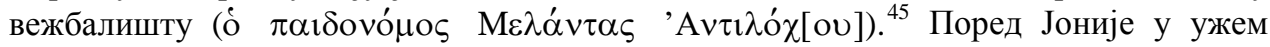
смислу, име Антилох је морало бити популарно и у другим јонским насеобинама у Малој Азији, као што то добро показује горе наведени случај грађанина Кизика на Пропонтиди, познатог са епитафа у Еретрији, а чији је отац носио карактеристично

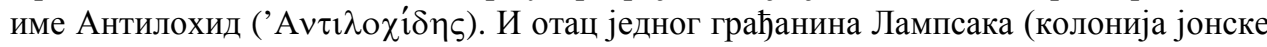
Фокеје), познатог са натписа из III века пре н.е. пронађеног на острву Родосу, звао се извесно Антилох. ${ }^{46}$ Да име није изгубило популарност и касније у царском периоду сведочи пример из Киоса (старе милетске колоније на Пропонтиди), где се херојско име Антилох јавља као лично име на једној великој листи ефеба, ала сада на римски начин, па грчко име заузима положај когномена - Марко Аурелије

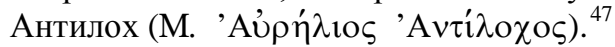

Шта је све могло утицати на давање херојских имена смртним људима можда се најбоље да видети на примерима употребе имена Антилох као антропонима у Тесалији. Име Антилох могло се јавити у тесалској антропонимији јер је, према нелеидској генеалогији, херој Антилох такође сматран и локалним тесалским херојем, али очигледно понајвише због везе Антилоха, Несторовог сина, са Ахилејем, Пелејевим сином и највећим ахајским јунаком под Тројом. ${ }^{48}$ Поносни на свог „националног“ хероја Ахилеја, Тесалци историјских епоха налазили су да је сасвим прикладно да деци надену име Ахилејевог миљеника. Од тесалских Антилоха који припадају класичној или ранохеленистичкој епоси (V-III век пре н.е.), један Антилох Тесалац споменут је већ у хипократовском спису $\dot{\pi} \pi \delta \eta \mu i ́ \alpha \iota$ из IV века. ${ }^{49}$ Из година после смрти Александра Великог је у тесалској Фери на једном великом списку гимназијараха Антилохово име забележено у патронимичком облику, док је име човека који је обављао функцију гимназијарха само делимично

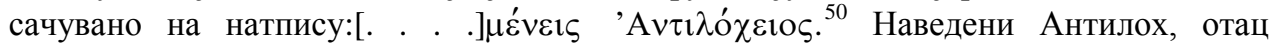
гимназијарха из Фере, морао је дакле бити рођен још у првој половини IV века, да би његов син могао обављати службу у последњим деценијама века. Занимљив је и

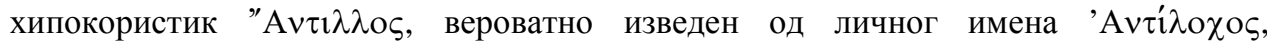
забележен у Хераклеји трахинској на крају III или у првим деценијама II века пре н.е. ${ }^{51}$ О популарности херојског имена Антилох као личног имена у Тесалији сведоче и сачуване потврде из познохеленистичког периода из више тесалских

\footnotetext{
${ }^{45}$ SEG 16, 651 (највероватније II век пре н.е.).

${ }^{46}$ Упор. LGPN VA, s.v. Antilochos (12).

${ }^{47}$ I. Kios 16, В II, 77 (датовање 108/9. год. н.е.). Упор. LGPN VA, s.v. Antilochos (2).

${ }^{48}$ Упор. нпр. J.-C. Decourt, A. Tziafalias, Mythological and Heroic Names in the Onomastics of Atrax (Thessaly), Old and New Worlds in Greek Onomastics (ed. E. Matthews), Proceedings of the British Academy 148, Oxford University Press, Oxford 2007, 17.

${ }^{49}$ Hp., Epid. II, 1, 10. Упор. LGPN IIIB, s.v. Antilochos (2).

${ }^{50}$ SEG 29, 552, col. А.3, 26 (датовање око 319. год. пре н.е.). Упор. LGPN IIIB, s.v. Antilochos (6).

${ }^{51}$ У декрету о проксенији за браћу Алексида ("А $\left.\lambda \varepsilon \xi \iota \varsigma\right)$ и Антила ("А $\tau_{\imath} \lambda \lambda \mathrm{\alpha}$ ), синове Аристеје из града Хераклеје у Трахинији. Упор. С. Habicht, Fremde Richter im ätolischen Delphi?, Chiron 17, München 1987, 90-1; LGPN IIIB, s.v. Antillos.
} 
градова: Атракса, Ларисе и Фере. ${ }^{52}$ Који су, опет, били разлози да се име Антилох као лично име јави у Фанотеју у Фокиди, није сасвим јасно, осим да је можда реч о популарности овог имена као панхеленског. Антилох се управо звао изабрани секретар (grammateus) Савеза Фокиђана из Фанотеја ( $ү \rho \mu \mu \alpha \tau \varepsilon \dot{o v \tau o \zeta ~ ' A v \tau \imath \lambda o ́ \chi o v ~}$

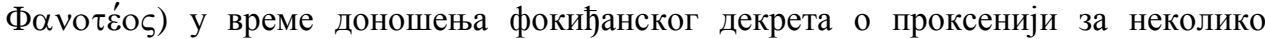
грађана тесалске Ларисе у другој половини III пре н.е. ${ }^{53}$ Вероватно се овде ради о популарности херојских имена као општој карактеристици хеленистичке епохе, исто као у случају јединог „македонског“ Антилоха, посведоченог у Египту у једном документу из истог периода. ${ }^{54} \mathrm{C}$ друге стране, ово није једини случај да је херојско име Антилох забележено као лично име у Египту. Од осталих „египатских“ Антилоха који сви припадају периоду Римског царства, пажњу нам је привукао документ из Антинојполиса где је посведочен човек по имену Хиполох

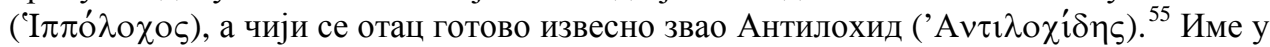
патрономичком облику (Антилохид) упућује, као што смо већ видели, на закључак да се и име Антилох могло и раније јавити као лично име у овој породици, односно да је чак могло бити присутно као антропоним кроз више генерација.

Поред Атике, највише потврда херојског имена Антилох као личног имена долази са острва Родоса. ${ }^{56}$ Оне углавном потичу из познохеленистичког периода. Име Антилох се понавља у појединим породицама кроз генерације као што је то, на пример, случај са „Антилосима“ потврђеним на великом натпису из Линда ${ }^{57}$ или, опет, на надгробном споменику Еуфрагоре чијих је више најближих рођака (деда, отац, као и син) носило име Антилох. ${ }^{58}$ С друге стране, међу Антилосима са Родоса хеленистичке епохе има епонимних свештеника бога Хелија које није увек тако лако идентификовати и прецизно датовати њихову службу. Наиме, име епонимног свештеника бележено је у званичним државним документима (сачуваним на епиграфским споменицима), као и на бројним амфорама са Родоса из хеленистичког периода, али најчешће тако да се само наводи име свештеника, не и његов

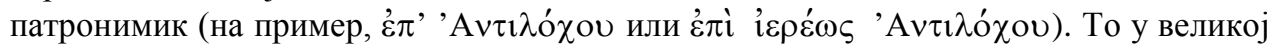
мери отежава датовање, пошто није сачувана листа епонимних свештеника и она се може само фрагментарно и делимично реконструисати. ${ }^{59}$ Међу Рођанима који су

\footnotetext{
${ }^{52}$ Упор. LGPN IIIB, s.v. Antilochos (4)-(5), (7).

${ }^{53}$ IG IX 1, 99, 4-5. Упор. LGPN IIIB, s.v. Antilochos (1).

${ }^{54}$ SB XVIII, 13841, 2. Упор. А. Tataki, Macedonians Abroad (MELETHMATA 26), Athens 1998, 248:

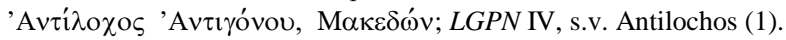

${ }^{55} S B$ V 8568, 2: 'I $\pi \pi[\mathrm{ó}] \lambda \mathrm{o} \chi \mathrm{o}\left[\varsigma_{\varsigma}^{\prime}\right.$ 'A $\left.\left.v\right] \tau \imath \lambda \mathrm{o} \chi[i]\right] \delta \mathrm{o}[\mathrm{v}]$.

${ }^{56}$ Од укупно 17 потврда које бележи први том оксфордског Лексикона грчких личних имена, најстарија је из ранохеленистичког периода (крај IV или почетак III века пре н.е.), а најмлађа из периода Царства (III века н.е.). Упор. $L G P N$ I, s.v. Antilochos (4) - (20).

${ }^{57}$ Lindos II 1, frg. J col. II 1, 34. Упор. LGPN I, s.v. Antilochos (18) - (19).

${ }^{58}$ IG XII 1, 168; Упор. LGPN I, s.v. Antilochos (13) - (15).

${ }^{59}$ Још je Hiller v. Gaertringen, RE Suppl. V, 1931, 834-840, s.v. Rhodos, међу првима покушао да унесе реда у листу епонимних свештеника бога Хелија. У међувремену се појавило неколико вредних студија на ту тему: за детаљну хронологију епонимних свештеника бога Хелија забележених на амфорама са Родоса, упор. G. Finkielsztejn, Chronologie détaillée et révisée des éponymes amphoriques rhodiens, de 270 à 108 av.
} 
носили херојско име Антилох било је и победника о панхеленским светковинама.

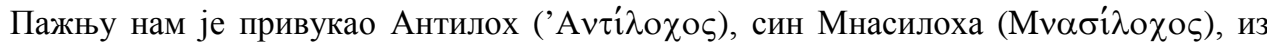
Камира на Родосу, који је негде у II веку пре н.е. победио на Истамским играма у трци коња. ${ }^{60}$ И у овом случају треба нагласити да име Антилох није морало бити дато искључиво са погледом на хероја Антилоха, већ, пре свега, у складу са раширеном грчком праксом да мушка деца задржавају део очевог, односно породичног имена у свом имену, што и код оца и сина (Мнасилох и Антилох) показује карактеристичан заједнички елемент $-\lambda \circ \chi о \varsigma$.

Остаје, међутим, да се одговори на питање зашто је херојско нелеидско име Антилох било тако популарно као лично име на дорском острву Родосу у хеленистичком периоду? Наведени примери могли би најпре да укажу на панхеленски карактер овог имена, што је нашло свог одраза у антропономији Родоса. Део одговора, међутим, треба тражити у чињеници да је Родос, нарочито у хеленистичком периоду, представљао богат трговачки полис који је као држава, али и поједине породице окренуте поморској трговини приватно, одржавао живе економске и политичке везе са многобројним хеленским и хеленизованим заједницама на широком простору Медитерана. ${ }^{61}$ Тиме везама се дају, чини се, објаснити разлози за популарност овог, али и неких других нелеидских имена (Нестор, Трасимед, Пејсистрат) као личних имена на Родосу. Можда оне стоје и у вези са „проналажењем сродства“ Рођана са оним Хеленима који су, по стандардима и мерилима, пре свега хеленистичке епохе, могли бити сматрани Нелејевим и Несторовим потомцима.

На крају, на основу свега изнетог, треба истаћи да смо овим радом учинили покушај да одговоримо на питање зашто се херојско име Антилох јавља као антропоним, односно зашто је било прихватљиво за давање новорођеној деци у одређеним срединама хеленског света и у одређеним историјским периодима. Све примере које смо анализирали покушали смо да ставимо у што јаснији историјски контекст, односно настојали смо да им се, колико је то могуће, да конкретан историјски садржај. Треба свакако напоменути да се неке од претпоставки изнетих у овом раду морају узети са знатном дозом резерве. Оно што је, међутим, сигурно је то да је лично име Антилох давано потомству у различитим епохама старе грчке историје са јасном свешћу да је херојско и нелеидско. Основни разлози који су допринели популарности имена Антилох као личног имена у старој Грчкој дају се свести на три најважнија: 1) пошто је реч о хероју истакнутом у традицији о Тројанском рату, његово се име може најпре посматрати као панхеленско и од значаја за све Хелене; 2) име Антилох је такође нелеидско име и као такво је кроз историју било прихватљиво нарочито Јоњанима 3) име Антилоха, који је као херој био пријатељ Ахилеја, највећег ахајског јунака под Тројом, али и националног

J.-C. environ. Premier bilan (BAR International Series 990), Oxford 2001. Ове податке је недавно успешно довео у склад са постојећим епиграфским материјалом С. Habicht, Rhodian Amphora Stamps and Rhodian Eponyms, Revue des études anciennes 105, Bordeaux 2003, 541-587.

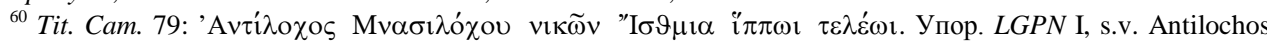
(16).

${ }^{61}$ Упор. нпр. V. Gabrielsen, The Naval Aristocracy of Hellenistic Rhodes, Aarhus 1997. 
хероја Тесалаца, постало је атрактивно такође Тесалцима који су и на тај начин, преко личних имена, настојали да истакну везу са славним претком. Овим разлозима појединачно, или свима њима заједно, може се делимично објаснити дистрибуција антропонима Антилох у грчком свету и његова нарочита популарност у одређеним областима старе Хеладе као што су Атика, Јонија, Тесалија, острво Родос.

Списак скраћеница епиграфских и лексикографских публикација:

Agora XV = B. D. Meritt, J. S. Traill, The Athenian Agora, XV. The Athenian Councillors, Princeton 1974.

Chantraine, $D E L G=$ P. Chantraine, Dictionnaire étymologique de la langue Grecque. Histoire des mots, I-IV, Paris 1968-1980.

DNP = Der neue Pauly: Enzyklopädie der Antike, hrsg. H. Cancik, H. Schneider, Stuttgart, Weimar 1996-2003.

Ét. Thas. III = J. Pouilloux, Recherches sur l'histoire et les cultes de Thasos I. De la foundation de la cité à 196 avant J.-C. (Études thasiennes III), Paris 1954.

FD III = Fouilles de Delphes III. Épigraphie, Paris 1909-1985.

$I G$ = Inscriptiones Graecae:

IG $\mathrm{I}^{3}=$ Inscriptiones Graecae I: Inscriptiones Atticae Euclidis anno anteriores. Berlin 1981-1994. Fasc. 1, ed. D. Lewis, Decreta et Tabulae Magistratuum (nn. 1-500); fasc. 2, ed. D. Lewis, L. Jeffery, Dedicationes. Catalogi. Termini. Tituli Sepulcrales. Varia. Tituli Attici Extra Atticam Reperti. Addenda (nn. 501-1517).

IG II $^{2}=$ Inscriptiones Atticae Euclidis anno posteriores, I-III, ed. J. Kirchner, Berlin 1913-1940.

$I G I^{2}{ }^{2} 1$ = Inscriptiones Graecae IV: Inscriptiones Argolidis. Fasc. 1, Inscriptiones Epidauri, ed. F. Hiller von Gaertringen. Berlin 1929.

IG IX 1 = Inscriptiones Graecae IX 1. Inscriptiones Phocidis, Locridis, Aetoliae, Acarnaniae, insularum maris Ionii, ed. W. Dittenberger, Berlin 1897.

IG XII 1 = Inscriptiones Graecae XII. Inscriptiones insularum maris Aegaei praeter Delum, fasc. 1. Inscriptiones Rhodi, Chalces, Carpathi cum Saro, Casi, ed. F. Hiller von Gaertringen, Berlin 1895.

IG XII 8 = Inscriptiones Graecae XII,8. Inscriptiones insularum maris Thracici, ed. C. Friedrich, Berlin 1909.

IG XII 9 = Inscriptiones Euboeae insulae, ed. E. Ziebarth, Berlin 1915.

I. Apollonia = P. Cabanes, N. Ceka, Corpus des inscriptions grecques d'Illyrie méridionale et d'Épire. I. Inscriptions d'Épidamne-Dyrrhachion et d'Apollonia. 2. Inscriptions d'Apollonia d'Illyrie, Athènes-Paris 1997.

I. Epidamnos = P. Cabanes, F. Drini, Corpus des inscriptions grecques d'Illyrie méridionale et d'Épire. I. Inscriptions d'Épidamne-Dyrrhachion et d'Apollonia. 1. Inscriptions d'Épidamne-Dyrrhachion, Athènes-Paris 1997.

I. Kalchedon = R. Merkelbach (Hrsg.), Die Inschrifen von Kalchedon (Inschriften griechischer Städte aus Kleinasien 20), Bonn 1980.

I. Kios $=$ T. Corsten (Hrsg.), Die Inschriften von Kios (Inschriften griechischer Städte aus Kleinasien 29), Bonn 1985.

I. Magnesia = O. Kern (Hrsg.), Die Inschriften von Magnesia am Maeander, Berlin 1900. 
I. Priene = F. Hiller von Gaertringen (Hrsg.), Inschriften von Priene, Berlin 1906.

I. Smyrna = G. Petzl (Hrsg.). Die Inschriften von Smyrna. Teil I: Grabschriften, postume Ehrungen, Grabepigramme; Teil II 1 (Inschriften griechischer Städte aus Kleinasien 23-24, 1), Bonn 1982-1987

$L G P N=$ A Lexicon of Greek Personal Names:

$L G P N$ I = P. M. Fraser, E. Matthews (edd.), A Lexicon of Greek Personal Names I: The Aegean Islands, Cyprus and Cyrenaica, Oxford 1987.

LGPN II = M. G. Osborne, S. G. Burne (edd.), A Lexicon of Greek Personal Names II: Attica, Oxford 1994.

LGPN III A = P. M. Fraser, E. Matthews (edd.), A Lexicon of Greek Personal Names IIIA: The Peloponnese, Western Greece, Sicily and Magna Graecia, Oxford 1997.

LGPN III B = P. M. Fraser, E. Matthews (edd.), A Lexicon of Greek Personal Names IIIB: Central Greece: From the Megarid to Thessaly, Oxford 2000.

LGPN IV = P. M. Fraser, E. Matthews (edd.), A Lexicon of Greek Personal Names IV: Macedonia, Thrace, Northern Regions of the Black Sea, Oxford 2005.

LGPN V A = Th. Corsten, R.W.V. Catling, M. Ricl (edd.), A Lexicon of Greek Personal Names V A: Coastal Asia Minor: Pontos to Ionia, Oxford 2010.

Lindos II = C. Blinkenberg, Lindos. Fouilles et recherches, II. Fouilles de l'acropole. Inscriptions, Berlin, Copenhagen 1941.

Milet $=$ Milet. Ergebnisse der Ausgrabungen und Untersuchungen seit dem Jahre 1899 (edd. Th. Wiegand et al.), Berlin 1906-2006.

$R E=$ Pauly-Wissowa (edd.), Real-Encyclopädie der classischen Altertumswissenschaft, Stuttgart 1893-1980.

Roscher = W. H. Roscher (ed.), Ausführliches Lexikon der griechischen und römischen Mythologie, Leipzig 1884-1937.

SB = Sammelbuch griechischer Urkunden aus Ägypten, edd. F. Priesigke, F. Bilabel, E. Kiessling, Hans-Albert Rupprecht, Vol. 1-18, 1915-1993.

SEG = Supplementum Epigraphicum Graecum, Leiden-Amsterdam 1923- .

Tit. Cam. = M. Segre, G. Pugliese-Carratelli, Tituli Camirenses, Annuario della Scuola Archeologica di Atene e delle Missione Italiane in Oriente XXVII-XXIX (Nuova Serie XI-XIII), 1949-1951.

\section{Литература:}

Bechtel, F., Die historischen Personennamen des Griechischen bis zur Keiserzeit, Halle 1917.

Burgess, J. S., Beyond Neo-Analysis: Problems with the Vengeance Theory, American Journal of Philology 118, Baltimore 1997, 1-19.

Burgess, J. S., The Tradition of Trojan War in Homer and the Epic Cycle, Baltimore 2001.

Davies, J. K., Athenian Propertied Families 600-300 B.C., Oxford 1971.

Decourt, J.-C., Tziafalias, A., Mythological and Heroic Names in the Onomastics of Atrax (Thessaly), Old and New Worlds in Greek Onomastics (ed. E. Matthews), Proceedings of the British Academy 148, Oxford University Press, Oxford 2007, 9-20.

Dowden, K., Homer's Sense of Text, Journal of Hellenic Studies 116, London 1996, 47-61.

Edwards, M. W., The Iliad. A Commentary, Vol. V, Books 17-20, Cambridge 1991.

Erbse, H., Nestor und Antilochos bei Homer und Arktinos, Hermes 121, Stuttgart 1993, 385-403.

Finkielsztejn, G., Chronologie détaillée et révisée des éponymes amphoriques rhodiens, de 270 à 108 av. J.-C. environ. Premier bilan (BAR International Series 990), Oxford 2001.

Gabrielsen, V., The Naval Aristocracy of Hellenistic Rhodes, Aarhus 1997. 
Gagarin, M., Antilochus' Strategy: The Chariot Race in Iliad 23, Classical Philology 78, Chicago 1983, 35-39.

Gantz, T., Early Greek Myth. A Guide to Literary and Artistic Sources, Baltimore 1993.

Habicht, C., Fremde Richter im ätolischen Delphi?, Chiron 17, München 1987, 87-95.

Habicht, C., Rhodian Amphora Stamps and Rhodian Eponyms, Revue des études anciennes 105, Bordeaux 2003, 541-587.

Herda, A., Der Kult des Gründerheroen Neileos und die Artemis Kithone in Milet, Jahreshefte des Österreichischen Archäologischen Institut sin Wien 67, Hauptblatt, Wien 1998, 1-48.

Janko, R., The Iliad. A Commentary, Vol. IV, Books 13-16, Cambridge 1994.

Kirk, G. S., The Iliad. A Commentary, Vol. I, Books 1-4, Cambridge 1985.

Knoepfler, D., Carystos et les Artémisia d'Amarynthos, Bulletin de Correspondance Hellénique 96, Athènes 1972, 283-301.

Meiggs, R., Athenian Empire, Oxford 1972.

Münsterberg, R., Die Beamtennamen auf den griechischen Münzen, repr. Hildesheim, Zürich - New York 1985.

Обрадовић, М., Мудраи Бијант из Пријене: традииија о времену у којем је живео, његовом пореклу и значењу његовог имена, Истраживања 22, Нови Сад 2011, 65-74.

Prinz, F., Gründungsmythen und Sagenchronologie (Zetemata 72), München 1979.

Richardson, N., The Iliad. A Commentary, Vol. VI, Books 21-24, Cambridge 1993.

Roisman, H., Nestor's Advice and Antilochus' Tactics, Phoenix 42, Toronto 1988, 114-120.

Solin, H., Die griechischen Personennamen in Rom. Ein Namenbuch, I-III, Berlin, New York 1982.

Tataki, A., Macedonians Abroad (MELETHMATA 26), Athens 1998.

Kamptz, H. von, Homerische Personennamen: sprachwissenschaftliche und historische Klassifikation, Göttingen 1982.

Visser, E., Homers Katalog der Schiffe, Stuttgart, Leipzig 1997.

West, M. L., Iliad and Aethiopis, Classical Quarterly 53, Oxford 2003, 1-14. 


\title{
THE HEROIC NAME ANTILOCHOS AS A PERSONAL NAME AMONGST THE GREEKS
}

\author{
Summary
}

This paper concerns the Greek heroic name Antilochos and examines its distribution as a personal name in the ancient Greek world, from the Archaic to the Roman Imperial period. The popularity of the name Antilochos as a personal name among the Greeks derives from the fact that in Homer and in later Greek epic tradition the hero Antilochos has many distinctive features that were highly appreciated by the Greeks. As a beloved son of Nestor, king of Pylos and the great hero of the Trojan Cycle, Antilochos is one of the bravest Achaean warriors who fought at Troy, and even lost his life trying to save his father. On the other hand, Antilochos, following the death of Patroklos, is also attested in tradition as a favorite and close companion of Achilles, the greatest hero of the Trojan War. At the funeral games that Achilles celebrated for Patroklos, Antilochos finished second in the chariot race "by his skill, not by the speed of his horses" (Il. XXIII 515), just as Nestor had advised him and also took part in the foot race. After Antilochos' death, his shade, along with those of Achilles and Patroklos, was believed to have gone to the Black Sea island later known as Leuke (the White Island). These were all the reasons why the heroic name Antilochos could also be acceptable as a personal name and desirable in the choice of names given to children and was attested as such in all periods and in almost all parts of the Greek world.

The personal name Antilochos could sound to the Greeks as a good Panhellenic name, but also as a name attractive particularly to the Athenians and the Ionians. The popularity of the name amongst the Ionians can be best explained with possible Neleid associations and connections, because the aristocratic elites in the Ionian cities mainly claimed Neleid ancestry (ostensibly descendents of Neleus, the son of Poseidon and the father of Nestor). The name Antilochos is thus attested as a personal name in Athens from an early date. Later and especially in the Classical period, it was widespread in various parts (demes) of Attica. It is also attested by the Ionians of Asia Minor in the several cities of the region, especially in inscriptions dating from the Late Hellenistic to the Imperial periods. The personal name Antilochos, on the other hand, is well attested as a personal name in Thessaly because of the hero Antilochos' associations with Achilles, the Thessalian national hero. Although not a Thessalian, the hero Antilochos could also be considered a Thessalian through his Neleid ancestry. There are many occurrences of the personal name Antilochos from other parts of the Greek world, but numerous attestations from the island of Rhodes, mostly from the Hellenistic period, attract special attention. It is, however, not uncommon for the name Antilochos, as the other personal 'Neleid' names (Nestor, Thrasymedes, Peisistratos), to be attested in a large number on the very island of Rhodes, as a large economic and trading centre of the Hellenistic world which maintained intensive economic and political relations with many Greek cities in a wide area of the Mediterranean basin.

Keywords: Antilochos, Greek anthroponymy, myth, Greek epic tradition, history, politics, cultural values. 